http://revped.ise.ro

Print ISSN 0034-8678; Online ISSN: 2559 - 639X

\title{
WALKING THE TIGHTROPE: CHALLENGES ENCOUNTERED IN NOVICE TEACHERS' PRACTICE
}

„Mersul pe sârmă”: provocări întâlnite de profesorii debutanţi în practica didactică

\section{Miruna Luana MIULESCU}

Journal of Pedagogy, 2020 (1), 115 - 136

https://doi.org/10.26755/RevPed/2020.1/115

The online version of this article can be found at: http://revped.ise.ro/category/2020/

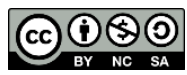

This work is licensed under the Creative Commons Attribution-NonCommercial-ShareAlike 4.0 International License.

To view a copy of this license, visit http://creativecommons.org/licenses/by-nc-sa/4.0/ or send a letter to Creative Commons, PO Box 1866, Mountain View, CA 94042, USA.

Published by:

Centrul Național de Politici și Evaluare în Educație

UNITATEA DE CERCETARE ÎN EDUCAȚIE

http://www.ise.ro/

https://rocnee.eu/

Further information about Revista de Pedagogie - Journal of Pedagogy can be found at:

Editorial Policy: http://revped.ise.ro/editorial-policy/

Author Guidelines: http://revped.ise.ro/the-writer-guide-2/ 


\title{
WALKING THE TIGHTROPE: CHALLENGES ENCOUNTERED IN NOVICE TEACHERS' PRACTICE
}

\section{Miruna Luana Miulescu*}

\author{
National Center for Policy and Evaluation in Education, \\ Education Research Unit, \\ Bucharest, Romania \\ miruna.miulescu@gmail.com
}

\begin{abstract}
The first years of teaching experience are crucial for beginning teachers as they face numerous challenges. Moreover, the way novices succeed in handling challenges during their first year of field work is a key determinant of their decision to continue working in the system or not. In this respect, a notable theme within the literature considers the experiences and challenges of beginning professionals, as more and more researchers talk about the "praxis shock", "reality shock" or "transition shock" to better depict the process through which new teachers pass in order to get accustomed to their new professional context. Our study seeks to investigate the challenging experiences that novice kindergarten teachers encounter, as well as the strategies they adopt in order to overcome them. The participants of the present study are beginning teachers $(n=16)$ with a maximum of three years' teaching experience from six public inner-city kindergartens. By making use of a phenomenological qualitative inquiry, data was collected through participating at semi-structured interviews, focus groups and by filling in logbooks. After the data was recorded and transcribed, five main themes were identified. The key findings indicate that a new professional context can often lead to uncertainty and discomfort. Moreover, beginning teachers' "challenging moments" descriptions generally emphasize their struggles concerning their own professional development, the school organizational aspects, as well as their relationships with students, colleagues, principals and parents. The results of the study show the need to restructure the collaboration process between novices and kindergartens, in order to improve
\end{abstract}

* Researcher, PhD, National Center for Policy and Evaluation in Education (NCPEE), Education Research Unit, Bucharest, Romania. 
collaborative relationships and provide the appropriate context for the professional development of kindergarten teachers at the beginning of their careers.

Keywords: challenging experiences, novice teachers, qualitative study, teacher education.

\section{Rezumat}

Primii ani de experien ă didactică sunt cruciali pentru profesorii începători, deoarece aceştia se confruntă cu numeroase provocări. Mai mult decât atât, modul în care debutan ii reuşesc să gestioneze provocările în primul lor an de muncă este un factor cheie în ceea ce priveşte decizia lor de a continua să lucreze în sistem. În acest sens, o temă importantă din literatura de specialitate explorează experien ele şi provocările educatorilor debutan $i$, întrucât tot mai mul $i$ cercetători vorbesc despre „şocul practicii”, „şocul realită ii” sau „şocul de tranzi ie" pentru a descrie mai bine procesul pe care noii profesori îl parcurg pentru a se obişnui cu noul lor context profesional. Studiul nostru investighează experien ele solicitante pe care le întâmpină profesorii începători din grădini ă, precum şi strategiile adoptate pentru a le depăşi. Participan ii studiului sunt cadre didactice debutante $(n=16)$ cu o experien a de predare de maximum trei ani, din şase grădini e de stat. In cadrul unei investiga ii calitative de tip fenomenologic, datele au fost colectate prin interviuri semi-structurate, focus grupuri şi prin analiza jurnalelor completate de participan ii la studiu. După prelucrarea şi analiza datelor, au fost identificate cinci teme principale. Cele mai importante constatări indică faptul că un nou context profesional poate duce adesea la incertitudine şi disconfort. Mai mult, descrierile „momentelor provocatoare" ale debutan ilor se referă, în general, la experien e legate de propria lor dezvoltare profesională, aspecte organizatorice, precum şi rela iile cu elevii, colegii, managerii şcolari şi părin ii. Rezultatele studiului arată necesitatea restructurării procesului de colaborare între debutan $i$ şi grădini e, în vederea imbunătă irii raporturilor de colaborare şi oferirii contextului adecvat pentru dezvoltarea profesională a educatorilor afla i la început de carieră.

Cuvinte-cheie: experien e solicitante, formarea profesorilor, profesori debutan $i$, studiu calitativ. 


\section{Introduction}

The successful retention of teachers has been on the international agenda for many years (OECD, 2005). A great deal of research has been dedicated to studying the effects of teachers' practices on student achievement (Darling-Hammond, 2014; Goe, 2007; Hattie, 2009) and consistent evidence suggests that teacher effectiveness actually contributes a great deal to student learning (Blömeke et al., 2016; Kunter et al., 2013). Evidences of both qualitative and quantitative analyses indicate that quality of teachers is undoubtedly the strongest correlate in student performance enhancement (Darling-Hammond, 2014).

Nevertheless, in spite of strong evidence that teacher quality is key to student success, there is no general agreement on which teacher characteristics have a significant contribution to student learning outcomes (Hattie, 2009; Rivkin et al., 2005; Scheerens, 2016). Student achievement has been linked to diverse factors from teacher's personal characteristics, such as verbal intelligence, self-efficacy and locus of control (Scheerens, 2016) to attributes which refer to professional's years of teaching experience, certification status or educational background (Darling-Hammond, 2000, 2014; Goe, 2007). Nonetheless, research which connects the educator's attributes to pupils' learning results is still relatively scarce.

In the context of quality teaching and learning, the current policy debate is focused on hiring and retention of teachers with major emphasis on professionals working with kindergarten children, as early childhood education plays a paramount role in children's development, learning, and well-being (OECD, 2019). It is a well-known fact that the first few years are decisive for teacher retention, as high quality professionals are expected to exit the system due to diverse factors. The body of literature which addresses why teachers leave the profession attributes the following reasons to the unsuccessful retention process, apart from personal reasons: lack of administrative support (Liu \& Meyer, 2005; Tye \& O’Brien, 2002), weakly organized or insufficient mentoring (Gratch, 1998), low salary (Tye \& O’Brien, 2002) or accountability issues (Darling-Hammond \& Sykes, 2003). 
In the present study, we will investigate in-depth the challenging experiences that novice teachers encounter during their work in kindergarten, as well as the strategies adopted in order to overcome them.

\section{Literature review}

The way novice teachers succeed in handling challenges in their first year of field work is a key determinant of their decision to continue working in the system or not (Sözen, 2018).

In this respect, a notable theme within the literature considers the experiences and challenges of beginning professionals. Kelchtermans and Ballet (2002) take notice of the "praxis shock" endured by novices when entering the new profession. On a similar note, Gordon and Maxey (2000) talk about "reality shock", and Corcoran (1981) refers to the "transition shock" to better depict the process through which new teachers pass in order to get accustomed to their new professional context.

Learning the ropes requires great effort on the novice's part, as he/she struggles with getting to know the students and learning the school's policies and procedures. Contrary to popular beliefs on the teacher's roles, beginning teachers spend a large amount of time on classroom management and administrative issues and less on teaching and learning (OECD, 2005). Being a teacher involves multiple and demanding tasks that most of them had not been adequately prepared for in their pre-service training (Nieme, 2002). Therefore, their expectations are not met and often frustration takes control. In addition, a newly graduate teacher cannot have the same competences as an experienced one. In spite of this, research shows that beginning professionals are expected to perform like their more experienced colleagues (Smith \& Sela, 2005); for instance, it is expected from them to handle the same workload as their more qualified fellow teachers, implement classroom activities efficiently, contribute substantially to their students' development progress, contribute to school development, etc.

The first years of teaching experience are crucial for beginning teachers as they face numerous challenges. According to prior research, novices need 
to find strategies to adapt to a new professional environment, interact with their colleagues, their students and their students' parents, efficiently organize their time, manage their class, organize their lessons, etc. (Çakmak et al., 2018).

Taking into account that they find themselves in unfamiliar conditions in which immediate decisions are required, it is imperative to find customized solutions to every particular problem which arises in practice. But their situation is not to their advantage: they have limited repertoires gained during pre-service practicum which translates to a lack of relevant experience to successfully cope with all the challenges. They often rely on their competences developed through their pre-service teacher training programme, but most of the time those are just not enough.

The educational literature of recent years is rich in scientific attempts to explore the complex process through which beginning teachers pass in order to successfully meet work demands. An expansion of interest has specifically been given to investigating newly qualified teachers' experiences related to stressful work contexts (McCann \& Johannessen, 2004; Veenman, 1984). Due to the nature of the topic, most of the studies deployed qualitativefocused research. For instance, McCann, Johannessen and Ricca (2005) analyze through structured interviews the challenges beginning teachers face, as well as their coping strategies. In their research, data shows that there are major categories that lead to novices' concern: relational problems (with students and their parents, fellow workers and supervisors); understanding of subject/curriculum, workload; evaluation of students' performances; autonomy and authority; appearance and teacher identity. As part of the research, the authors advance some possible solutions to the problems they are confronted with: carefully designed mentoring programs, the expanding of the network of teacher contacts or realistic teaching assignments.

On a similar note, Aarts, Kools and Schildwacht (2019) discuss the complex difficulties graduates experience in their first years of teaching. The researchers conducted a study on 35 secondary school teachers in their first and second year of employment. Even though the results show a shift in their challenges between the less experienced group and the more experienced one (one year apart), their major tension is attributed to the teaching process 
itself. More specifically, early-career teachers are confronted mainly with choosing the best teaching strategies for their students, concentrating on student's learning process, objectively assessing students' performances, efficiently managing the group of students or combating discipline issues. Other areas of tension for novices are related to workload and organizational aspects of the school (i.e., multitude of non-teaching tasks).

Pillen, Beijaard and den Brok (2013) carried out a study with the aim of assessing 141 novice teachers' daily uplifts and hassles, as well as their well-being. By using a diary method, the researchers gained a deeper understanding of the work-related stressors in the early-graduates' transition to their profession. Data shows that daily stressful moments are related to the teaching process and relation with other colleagues. At the same time, the study investigates the uplifting moments, which bring satisfaction to beginning teachers, as compared to other studies which direct their attention to the negative picture of the novices' professional life.

The complex nature of teaching was also depicted in a study conducted by Britt (1997) in which she investigates the new teachers' perceptions of their first teaching experiences. The findings show that these experiences are not all positive, many new graduates facing stress as they try to navigate the new work context. The problematic aspects perceived by novices fall into the following themes: class and school discipline, time management, preparation for lessons and parental involvement.

\section{Methodology}

As we already stated, this study's main objectives are to explore the challenging experiences that novice teachers encounter during their work in kindergarten, as well as the strategies adopted in order to overcome them. In this direction, we will discuss the meaning of these experiences and its significance in the process of building their professional identity. To accomplish this aim, the study is designed as a phenomenological qualitative inquiry. The phenomenology design was chosen because the focus is on comprehensively understanding the participants' experiences on a particular phenomenon. The particular phenomenon under study is explored through 
collecting data (qualitative methods) and discovering commonalities between the participants' perceptions (Marshall \& Rossman, 2011). Thus, the phenomenological design contributes to the real-life experiences of novice teachers about challenging experiences in public kindergartens in the Romanian educational system.

\subsection{Research participants}

In the case of beginning teachers, the person who is not yet experienced in teaching is called "novice". Although this term refers to a professional who is just at the start of his/her teaching career, there are still debates on whether this stage lasts for one, two or five - year period. For instance, according to Haynes (2011), teachers cease to be called novices after two or less years of teaching experience. Contrary to this opinion, Kim and Roth (2011) argue that newly qualified teachers can be called this way up to five years of field work. Another relevant study (Davis et al., 2006) defines a beginning teacher as pre-service professionals as well as those in their first year of work. Even though the literature defines distinct novice teacher profiles, for the purpose of this paper, beginning teachers are considered the professionals who have been working for less than 3 years.

In the present study, the participants were selected based on availability (or convenience sampling; i.e. collecting samples that are conveniently located and willing to be involved in the study) (Teddlie \& Yu, 2007). As Patton (2002) pointed out, convenience sampling is extensively used in qualitative research for analyzing cases that can yield richness of information related to the phenomenon of interest. Therefore, the selection of participants resorted to a convenience sample of individuals, and was based on certain criteria, such as: professional experience of a maximum of three years of teaching experience, teaching the same age group (teaching in kindergarten), recently completed Bachelor degree studies in Pre-School and Primary Educational Pedagogy, as well as availability and eagerness to participate.

The participants of this study are novice teachers $(n=16)$ meeting the above written criteria, alumna of the Pre-School and Primary Educational Pedagogy programme in the Faculty of Psychology and Educational Sciences, 
part of the University of Bucharest in Romania. Moreover, they are between ages of 22 and 31 years old, and work in similar contexts (6 inner-city kindergartens).

In the first phase of the sampling process, we contacted 28 novice teachers and gave them an extensive explanation of their future involvement in the research process. Only 16 of them agreed to take part in the study. The fact that almost half of the initial group decided to be out can be explained by the demands of keeping record of various experiences in a logbook. The logbook serves to keep record of important events and must be filled in daily for two weeks. It seems that this was the main constraint as perceived by the beginning teachers.

\subsection{Data Collection}

Since data gathering process is an essential part of a research, careful consideration had been given to developing data collection procedures, choosing the most suitable methods to gather qualitative information on specific variables and building a robust monitoring strategy of the entire process. Specifically, novice teachers were requested to use logbooks for the first two weeks of their practice in kindergarten. The participants had to write in the logbook on a daily basis about their most challenging experiences during their teaching. This autobiographical tool was not filled in thoroughly with their field experiences by all teachers, the reason being its timeconsuming nature. Therefore, because this technique did not work out as expected, two other qualitative instruments were employed in order for the teachers to elaborate on their field experiences: semi-structured interviews (with the 5 teachers who did not successfully complete the logbooks) and focus groups (3 focus groups which involved all participants).

The logbook was selected as a methodological tool so the teachers could describe their subjective perception of challenging moments in their teaching. As evidenced by numerous authors (Clemente et al., 2017; Romano, 2005), this narrative tool has descriptive purposes through which the researcher can explore and better understand the person's experiences about a phenomenon. 
Prior to this research, a study employing the phenomenological approach was conducted by Romano (2005), in which she explored "bumpy moments" in teacher education as a way to analyse pre-service teachers' understandings of their teaching experiences. In our study, the investigative tools (logbook, interview and focus group) were designed based on the methodological instruments developed through Romano's study. The logbook and interview items were the following:

(1) Please describe the challenging experiences you encountered during your teaching.

(2) How did you deal with it?

(3) Did you need anyone's help in handling it?

(4) Do you feel you have learned something from this experience? Please elaborate on your answer.

The semi-structured interview was chosen as a data gathering instrument as it is one of the most applied tools for generating information in educational research and gaining insight into people's thoughts and experiences (Denscombe, 2010). The focus group was selected as an appropriate methodological tool in the context of the present study based on its potential to elicit information and view sharing between participants in a short period of time (Kuckartz \& Rädiker, 2019). The semi-structured interviews and focus groups lasted approximately 20-30 minutes and 60-70 minutes, respectively. The teachers agreed to be audiotaped for a further analysis of their answers.

\subsection{Data analysis}

The logbook, interview and focus group data were analysed using qualitative content analysis (Bernard \& Ryan, 2010; Strauss \& Corbin, 1990) in order to delve more into the data. The data was transcribed verbatim and then analysed. The first phase consisted of identifying codes, then the codes were divided into different 15 categories across the data. Finally, these were listed under five main themes: 
Table no. 1. Teacher challenges - Coding Scheme

\begin{tabular}{|l|l|}
\hline Theme & Category \\
\hline The teacher & $\begin{array}{l}\text { Professional autonomy } \\
\text { Professional identity }\end{array}$ \\
\hline \multirow{3}{*}{ School organization } & $\begin{array}{l}\text { Workload } \\
\text { Bureaucracy } \\
\text { Teaching commitments } \\
\text { School and classroom resources }\end{array}$ \\
\hline \multirow{3}{*}{ Relationships with students } & $\begin{array}{l}\text { Motivating students } \\
\text { Individual differences } \\
\text { Classroom management } \\
\text { Dealing with undisciplined students }\end{array}$ \\
\hline \multirow{2}{*}{ Relationships with colleagues and principals } & $\begin{array}{l}\text { Collaboration with other teachers, } \\
\text { principal, other kindergarten workers } \\
\text { Feedback and guidance } \\
\text { Mentoring }\end{array}$ \\
\hline \multirow{2}{*}{ Relationships with parents } & $\begin{array}{l}\text { Interaction with parents/child's family } \\
\text { Parents' involvement in kindergarten } \\
\text { activities }\end{array}$ \\
\hline
\end{tabular}

\section{Findings}

\subsection{The teacher - identity and autonomy}

Veenman (1984) explains that the first-year experience of teaching can be "a dramatic and traumatic one" (p. 143), as most novices experience the transition from initial teacher training period to teaching profession with emotional distress and many struggles. The wide-ranging demands are also reflected in the category concerning the teacher's identity and autonomy. During the last few decades, the teacher's professional identity has become a prominent area of research (Beauchamp \& Thomas, 2009; Olsen, 2010), as it can be used as a resource for researchers to analyze teacher's learning and development.

In our study, reality shows that all beginners had experienced tensions regarding their professional identity. Most of them characterized the first few weeks of kindergarten as a "struggle". As the shift between faculty and workplace is a very dynamic and complex process, the novice is often in the situation where she/he has to count on the others' experiences and advice or their own (from practicum period). The tensions are caused when all these sources are experienced as conflicting or clashing. 
Researchers have agreed that tensions can have a considerable significance in professional identity development, as stressful experiences force the novice to question his/her own beliefs and practices (Alsup, 2006; Olsen, 2010). Nevertheless, some experiences could lead to profound emotional consequences for their development and functioning, as a novice explained:

"I feel at a loss right now because I was taught in a, let's say, constructivist teaching approach, and in my kindergarten, my mentor has a very traditional approach. I just feel it isn't right. I know it because the children are not happy, are not satisfied. I am afraid I will become like the teacher I had when I was young." (Participant with 2-years teaching experience)

Teacher autonomy is perceived as a pivotal element in quality teaching and learning (Huang et al., 2019). Researchers stress the importance of teacher autonomy, since a sense of powerlessness among newly qualified teachers could potentially lead to stress and anxiety (Aoki, 2002; Billett, 2001). In terms of describing the autonomous teacher, different views can be identified, the most prominent being the one belonging to Gabryś-Barker (2017): "fully competent, motivated by having a calling and a positive attitude to his or her students, which allows him or her to facilitate the learning process by creating a favorable classroom atmosphere" (p.175).

In our study, the majority of newly graduates (13 out of 16) have emphasized their struggles regarding the need to keep a balance between their work in the classroom and the organizational aspects of the kindergarten. Not surprisingly, many have confessed that they find all the demands confusing: "There are so many tasks every single day and I always leave the kindergarten drained of my energy. And I find perplexing that there are more and more tasks (not all concerning my class)." (Participant with 1-year teaching experience)

\subsection{School organization}

All novice teachers reported that bureaucracy represents a major constraint on their teaching-related assignments. Moreover, factors such as workload and limited amount of time cause many beginning teachers to feel a sense of unfulfillment. Such situations could lead to weakened morale and job dissatisfaction, as some participants have reported: 
"I feel taken aback by all the assignments that are not related to teaching. I really wanted to be a teacher, but these days I really struggle with motivating myself to go to work." (Participant with 1-year teaching experience)

In line with our findings, other studies (Butt \& Lance, 2005; Naylor \& White, 2010) also confirm that all teachers, irrespective of their seniority, are assigned complex tasks, many unrelated to teaching. Some study participants even described that at the end of the day, during their personal time, they still have to keep up with the demands and this interferes with their family time:

"In trying to fulfill all my work responsibilities, I find it very hard to keep a balance between my work and my private life. Needless to say that some parents call me on weekends... I know that I am their children's teacher and I have a huge contribution to their development, but this is just too much." (Participant with 2-years teaching experience)

\subsection{Relationships with students}

Novices found it challenging when they dealt with individual differences among students. This was a pervasive mentioned problem, as all the teachers found it difficult to cope with. Addressing the needs of a diverse student population is a challenge even for experienced teachers, but sometimes early-graduates are expected to take on special needs students since their first day of kindergarten.

"I have 2 children with special education needs in my class. One is diagnosed with Asperger syndrome and the other with ADHD. Sometimes it is really difficult for me to handle a class of 20 fiveyear olds." (Participant with 1-year teaching experience)

In order to successfully manage this kind of situation, beginning teachers make an effort to establish their own strategies, with the help of their colleagues. Some of them even contact their professors at university or former faculty colleagues to get as much professional help as possible:

"From my first year in kindergarten until now I have talked regularly with other former colleagues at faculty and to one of my professors whenever I find myself in a difficult situation." (Participant with 2years teaching experience) 
Another great source of stress is represented by the undisciplined students. Many research participants have highlighted the fact that they are struggling to handle the situations when children misbehave towards the teacher or their colleagues. Discipline issues can be hard to handle, even more so for novices. Also, novices could get frustrated by challenging moments such as the ones where they cannot keep the class quiet. Most of the times, especially when they meet a new group of children, unexperienced teachers find it hard to manage a group of 15-20. One teacher wrote the following in her logbook:

"My first day was chaotic. I did not know where to look, because every time I was getting distracted by a child or a group of children." (Participant with 2-years teaching experience)

In this kind of situation, some novices found help by asking other colleagues for support, reminding themselves the strategies they learned in their initial training or observing how other teachers manage thier own group of children. One teacher explained:

"Seeing that I cannot manage my group properly, I tried to notice how other teachers succeed in handling their classes. I decided that I have to be more firm when I ask them to do something. Also, I have to decide together with the students a set of rules that everyone has to abide by. I need more structure and so do they." (Participant with 2-years teaching experience)

4.4. Relationships with colleagues and principals

New teachers have different needs in comparison to the more-experienced ones. In order to grow professionally, there have to be efficient induction programs in helping newcomers to the kindergarten. Unfortunately, reality shows us that, most of the times, novices persevere and struggle to adjust to the new environment without asking for help. Moreover, they sometimes receive insufficient, inconsistent or no feedback and guidance from colleagues and principals.

"I remember that in my first week I was overwhelmed by everything. I thought of asking my colleagues of better ways of managing the group of children, designing my lessons and communicating with 
parents, but I did not receive any response. [...] It might have been because they were as overwhelmed by activities as much as I were." (Participant with 1-year teaching experience)

Support from colleagues can help newly-graduates in assessing their practices and experiences, as well as help them become more confident in their own career development:

"I remember that in my first year of teaching, one of my colleagues that I greatly respected told me that I should be always asking for help when I find myself lost because it is normal to feel like that in the beginning. With her help, I learned a lot, the mistakes I made." (Participant with 2-years teaching experience)

Encouragement from principals and older colleagues is much appreciated from the novices' part, but constructive feedback is much more valued. New teachers feel the need to learn and improve, and genuine support gives them a sense of confidence in their own practice. As a teacher with one year of teaching experience noted:

"I feel that my principal believes in me and my ideas to improve the lessons. I know that I am just starting to get the hang of it, but it helps a lot to know that someone is willing to answer your questions when you need a trustworthy answer." (Participant with 1-year teaching experience)

\subsection{Relationship with parents}

A major area of dissatisfaction was represented by the problematic relationship with parents and families which covered several aspects. On the one hand, some of the novices complained about the lack of interest on behalf of the parents, as well as the insufficient support for their plans for sustaining the children's learning development. On the other hand, other novices described the challenging situation where some of the parents were overeagerly involved in the classroom life, by imposing their own rules (e.g., special emphasis on order and quiet in the classroom, and best pedagogical practices in their perspective), or displaying an overprotective behavior by staying in class and nursing their child for several hours a day, even though the institutional rules do not allow this. 
Moreover, early graduates reported that some parents placed tremendous pressure on teachers through comments made during kindergarten visits or angry phone calls, this being a result of the lack of trust of parents in the novices' abilities to manage the class and provide valuable learning opportunities for their children.

One of the kindergarten teachers wrote the following in her logbook:

"Teaching is a wonderful profession, but I encountered daily so many difficulties with parents that it is starting to get me annoyed. Lately, parents have been giving me lots of suggestions, and some of them sound ridiculous (e.g., to let his child sit in my lap all day long because he dearly misses his parents, even if this is his child's $2^{\text {nd }}$ year in kindergarten and I have other 18 children to take care of; also, I do not have another colleague with me in class). It is really exhausting. I have never believed it could be this tiring to work with parents." (Participant with 1-year teaching experience)

Failing in consolidating a successful parent-teacher relationship could be very discouraging and stress-provoking for novices. Confronting themselves with this kind of challenge, some novices have already asked their more experienced colleagues for advice:

"After the first few days, I observed that I am failing in trying to communicate well with all the parents. [...] Therefore, I asked for help and my more experienced colleagues taught me some strategies and talked about their own experiences with parents. It also helped that I have other first-year colleagues with the same problem. [...] I admit I am glad that I am not the only one who has this problem, because it would have been harder to keep it to myself." (Participant with 1-year teaching experience)

\section{Discussion and conclusions}

Starting a career in teaching brings about substantial change in one's life, both professionally and personally. In the process of taking control over their teaching, novices pass through several experiences and encounter diverse internal and external factors which shape their understanding of the new 
work context. Clark accurately describes the beginning stages of working in kindergarten as "an emotional roller coaster filled with nerves, exhilaration, and uncertainty" (Clark, 2012, p. 197), as the teacher is now not solely responsible for his/her own learning, but for the children's development and well-being. Moreover, the stressful situations can have a strong impact on the teachers' professional performance, as well as on student outcomes, as highlighted by Arens and Morin (2016).

The experiences reported by kindergarten teachers as challenging, often result in emotional stress or even burnout, leading some of the novices to exiting the profession (Dicke et al., 2015). There is wide agreement that the transition from university to the kindergarten/school setting is often associated with feelings of helplessness or frustration. The demands of a new professional context can often lead to uncertainty and discomfort.

This qualitative study, which includes a total of 16 participants, offers some insights regarding the type of situations novice teachers encounter in their daily practice at kindergarten and the strategies they develop in order to handle them successfully. Our findings indicate that beginning teachers' "challenging moments" descriptions generally emphasize their struggles concerning their own professional development, the school organizational aspects, as well as their relationships with students, colleagues, principals and parents. These results were not surprising since most of the studies that investigate novices' concerns come to the same conclusion (Aarts et al., 2019; Çakmak et al., 2018).

The newly graduates often talk about the support and guidance they received from their more or less experienced colleagues, principals and even former faculty colleagues. In most cases, these people are considered to be the most protective factors in the novices' professional development. On the other hand, our research indicates that the attitude of some of the novices' colleagues and children's parents, as well as their lack of solidarity was perceived by some of the beginning teachers as a constraint on their professional development. Oftentimes, seeking help from another person who may provide another perspective can help greatly in dealing with their own struggles. Thus, it is paramount for principals and more experienced teachers to be aware they play a pivotal role in professional support and 
guidance, as well as in building and maintaining relational trust within the teachers' group so the novice feels he/she is part of a trustworthy community.

The situations reported by beginners were perceived as challenging because they used strategies from their own limited repertoires gained during preservice practicum. Also, some even relied on their intuition to solve problems, which of course can be of value at times, but not always. A mentorship program might prove to be helpful for the novices, as some studies show (Gratch, 1998; Haynes, 2011). In the current study, only some beginners benefited from mentoring program, but even in those cases, the relationship was not very structured and handled very well at all times. Our findings illustrate that six of our teachers sought help when confronted with organizational aspects or managing individual differences among students, but they could not get any support. Unfortunately, in these situations the teacher is left to handle all instructional, organizational and emotional difficulties on his/her own.

Some of the literature on novice teachers focuses on blaming initial teacher education for the problems and struggles newly graduates face in kindergartens and schools. While teacher training can indeed have some deficiencies, it is unrealistic to expect such a short period of time (i.e., 3 years) could adequately equip and prepare the new teacher for all the diverse experiences he/she will encounter in daily practice. Also, theoretical courses and initial practice cannot simulate every single future problematic situation.

Therefore, we believe that criticism in this regard is only partly justified and bigger emphasis should be placed upon a well-designed collaboration process between novice and the educational workplace, with the help of principals. Nevertheless, connection with other novice professionals should be encouraged, as they support each other while gradually developing practices. Designing a high-quality mentorship or collaboration program should be based on studies which investigate novice teachers' voices, their successes, as well as their fears and struggles. All these aspects need to be taken into account in order to provide the novice (mentee) - experienced teacher (mentor) relationship a framework for enhancing meaningful collaboration and support. 
With regards to the limitations of our study, we consider that, although we tried to carry on a thorough research on the novice teachers' struggles, this is a small-scale study mainly based on collecting data from 16 beginning kindergarten teachers through qualitative instruments. Furthermore, the results cannot be transferred to other situations (e.g., higher grades or kindergartens in rural areas), and there is an evident limitation of gender parity, but this situation is a consequence of the fact that there are only a few male educators in the whole country. However, individual experiences and reflections on the most challenging moments newly graduates are confronted with can communicate to us a great deal about the type of situations these professionals encounter on a daily basis and the way they succeed in managing them. Our findings are consistent with those of other studies and nuance them to some extent.

Although there are some limitations of the study, such as the involvement of different ages of novice teachers and a small sample size, these findings contribute to some extent to shaping the future of education. Furthermore, we must be aware of the impact of novices' experiences on their decision to continue or end their teaching journey. Nevertheless, further studies are necessary in order to deepen on what novices, kindergartens and universities can develop and put into practice to foster novices' professional development and well-being.

\section{References}

- Aarts, R., Kools, Q., \& Schildwacht, R. (2019). Providing a good start. Concerns of beginning secondary school teachers and support provided. European Journal of Teacher Education, 1-19.

https://doi.org/10.1080/02619768.2019.1693992

- Alsup, J. (2006). Teacher identity discourses: Negotiating personal and professional spaces. Erlbaum.

- Aoki, N. (2002). Aspects of teacher autonomy: Capacity, freedom and responsibility. In P. Benson \& S. Toogood (Eds.), Learner autonomy 7: Challenges, research and practice (pp. 111-135). Authentik.

- Arens, A. K., \& Morin, A. J. S. (2016). Relations between Teachers' Emotional Exhaustion and Students' Educational Outcomes. Journal of Educational Psychology, 108(6), 800-813. https://doi.org/10.1037/edu0000105

- Beauchamp, C., \& Thomas, L. (2009). Understanding teacher identity: an overview 
of issues in the literature and implications for teacher education. Cambridge Journal of Education, 39(2), 175-189. https://doi.org/10.1080/03057640902902252

- Bernard, H. R., \& Ryan, G. W. (2010). Analyzing qualitative data: Systematic approaches. Sage.

- Billett, S. (2001). Learning through work: Workplace affordances and individual engagement. Journal of Workplace Learning, 13(5), 209-214.

- Blömeke, S., Olsen, R. V., \& Suhl, U. (2016). Relation of student achievement to the quality of their teachers and instructional quality. In T. Nilsen \& J.-E. Gustafsson (Eds.), Teacher quality, instructional quality and student outcomes. IEA Research for Education 2 (pp. 21-50). Springer.

- Britt, P. M. (1997). Perceptions of beginning teachers: Novice teachers reflect upon their beginning experiences [Paper presentation]. Annual Meeting of the Mid-South Educational Research Association, Memphis, TN. https://files.eric.ed.gov/fulltext/ED415218.pdf

- Butt, G., \& Lance, A. (2005). Secondary Teacher Workload and Job Satisfaction. Educational Management Administration \& Leadership, 33(4), 401-422. https://doi.org/10.1177/1741143205056304

- Çakmak, M., Gündüz, M., \& Emstad, A. B. (2018). Challenging moments of novice teachers: survival strategies developed through experiences. Cambridge Journal of Education, 49(2), 147-162. https://doi.org/10.1080/0305764X.2018.1476465

- Clemente, V., Tschimmel, K., \& Marques Vieira, R. (2017). Why a Logbook? A backpack journey as a metaphor for product design education. The Design Journal, 20(1), S1530-S1542. https://doi.org/10.1080/14606925.2017.1352677

- Corcoran, E. (1981). Transition Shock. The Beginning Teacher's Paradox. Journal of Teacher Education, 32(3), 19-23. https://doi.org/10.1177/002248718103200304

- Darling-Hammond, L. (2000). Teacher quality and student achievement: A review of state policy evidence. Education Policy Analysis Archives, 8(1), 1-44. https://doi.org/10.14507/epaa.v8n1.2000

- Darling-Hammond, L. (2014). Strengthening clinical preparation: The holy grail of teacher education. Peabody Journal of Education, 89(4), 547-561. https://doi.org/10.1080/0161956X.2014.939009

- Darling-Hammond, L., \& Sykes, G. (2003). Wanted: A national manpower policy for education. Education Commission of the States.

- Davis, E. A., Petish, D., \& Smithey, J. (2006). Challenges new science teachers face. Review of Educational Research, 76(4), 607-651. https://doi.org/10.3102/00346543076004607

- Denscombe, M. (2010). The good research guide for small-scale social research projects (4th ed.). Open University Press.

- Dicke, T., Parker, P. D., Holzberger, D., Kunina-Habenicht, O., Kunter, M., \& Leutner, D. (2015). Beginning Teachers' Efficacy and Emotional Exhaustion: 
Latent Changes, Reciprocity, and the Influence of Professional Knowledge. Contemporary Educational Psychology, 41, 62-72.

https://doi.org/10.1016/j.cedpsych.2014.11.003

- Goe, L. (2007). The link between teacher quality and student outcomes: A research synthesis. National Comprehensive Center for Teacher Quality.

- Gordon, S. P., \& Maxey, S. (2000). How to Help Beginner Teachers Succeed. Association for Supervision and Curriculum Development.

- Gratch, A. (1998). Beginning teacher and mentor relationships. Journal of Teacher Education, 49(3), 220-227.

- Haynes, L. (2011). Novice teachers' perceptions of their mentoring experiences. ProQuest Dissertations \& Theses (PQDT).

- Hanushek, E. A., Kain, J. F., O'Brien, D. M., \& Rivkin, S. G. (2005). The Marketfor Teacher Quality. National Bureau for Economic Research.

- Hattie, J. A. (2009). Visible learning: A synthesis of 800+ meta-analyses on achievement. Routledge.

- Huang, J., Lock, K. Y. N., \& Teng, F. (2019). Autonomy in English Language Teaching: A Case Study of Novice Secondary School Teachers in Hong Kong. Chinese Journal of Applied Linguistics, 42(1), 3-20.

https://dx.doi.org/10.1515/cjal-2019-0001

- Kelchtermans, G., \& Ballet. K. (2002). The Micropolitics of Teacher Induction. A Narrative-Biographical Study on Teacher Socialisation. Teaching and Teacher Education, 18(1), 105-120.

- Kim, K., \& Roth, G. (2011). Novice teachers and their acquisition of work-related information. Current Issues in Education, 14(1), 1-28.

- Kuckartz, U., \& Rädiker, S. (2019). Analyzing Focus Group Data. In U. Kuckartz \& S. Rädiker, Analyzing Qualitative Data with MAXQDA (pp. 201-217). Springer International Publishing.

- Kunter, M., Klusmann, U., Baumert, J., Richter, D., Voss, T., \& Hachfeld, A. (2013). Professional competence of teachers: Effects on instructional quality and student development. Journal of Educational Psychology, 105(3), 805820. https://dx.doi.org/10.1037/a0032583

- Liu, X. S., \& Meyer, J. P. (2005). Teachers' perceptions of their jobs: A multilevel analysis of the teacher follow-up survey for 1994-95. Teachers College Record, 107(5), 985-1003. https://doi.org/10.1111/j.1467-9620.2005.00501.x

- Marshall, C., \& Rossman, G. B. (2011). Designing qualitative research. Sage Publications.

- McCann, T. M., \& Johannessen, L. R. (2004). Why Do New Teachers Cry?. The Clearing House: A Journal of Educational Strategies, Issues and Ideas, 77(4), 138-145. https://doi.org/10.3200/TCHS.77.4.138-145

- McCann, T. M., Johannessen, L. R., Ricca, B. P. (2005). Supporting Beginning English Teachers: Research and Implications for Teacher Induction. National 
Council of Teachers of English.

- Naylor, C, \& White, M. (2010). The Worklife of BC Teachers in 2009. BC Teachers' Federation.

http://bctf.ca/uploadedFiles/Public/Issues/WorklifeWorkload/2009/FullReport.pdf

- Nieme, H. (2002). Active learning — a cultural change needed in teacher education and schools. Teaching and Teacher Education, 18(7), 763-780.

- OECD. (2005). Teachers Matter: Attracting, Developing, and Retaining Effective Teachers. OECD Publishing.

- OECD. (2019). Providing Quality Early Childhood Education and Care: Results from the Starting Strong Survey 2018. TALIS, OECD Publishing.

- Olsen, B. (2010). Teaching for success: Developing your teacher identity in today's classroom. Paradigm.

- Patton, M. Q. (2002). Qualitative research and evaluation methods. Sage Publications.

- Rivkin, S. G., Hanushek, E. A., \& Kain, J. F. (2005). Teachers, schools, and academic achievement. Econometrica, 73(2), 417-458. https://doi.org/10.1111/j.1468-0262.2005.00584.x

- Romano, M. E. (2005). Preservice teachers' reflections on observed "bumpy moments" in teaching: Implications for teacher education. The Teacher Educator, 40(4), 257-277. https://doi.org/10.1080/08878730509555365

- Salvo, J. C., Kibble, L., Furay, M. A., \& Sierra, E. A. (2005). Surviving Day One ... and Beyond. Supporting New Educators, 62(8), 24-28.

- Scheerens, J. (2016). Educational effectiveness and ineffectiveness. A Critical Review of the Knowledge Base. Springer Science+Business Media Dordrecht.

- Smith, K., \& Sela, O. (2005). Action Research as a bridge between pre-service teacher education and in-service professional development. The European Journal of Teacher Education, 28(3), 293-311.

https://doi.org/10.1080/02619760500269418

- Sözen, P. H. (2018). Challenges of Novice Teachers. International E-Journal of Advances in Education, 4(12), 278 - 282. https://doi.org/10.18768/ijaedu.478254

- Strauss, A., \& Corbin, J. M. (1990). Basics of qualitative research: Grounded theory procedures and techniques. Sage Publications.

- Teddlie, C., \& Yu, F. (2007). Mixed Methods Sampling: ATypology with Examples. Journal of Mixed Methods Research, 1(1), 77-100. https://doi.org/10.1177/2345678906292430

- Tye, B. B., \& O'Brien, L. (2002). Why are experienced teachers leaving the profession? Phi Delta Kappan, 84(1), 24-32. http://dx.doi.org/10.1177/003172170208400108

- Veenman, S. (1984). Perceived Problems of Beginning Teachers. Review of Educational Research, 54(2), 143-178. 
http://dx.doi.org/10.3102/00346543054002143

- Wiswall, M. (2013). The dynamics of teacher quality. Journal of Public Economics, 100, 61-78. https://doi.org/10.1016/j.jpubeco.2013.01.006

The online version of this article can be found at: http://revped.ise.ro/category/2020-en/

\section{$(C C)$ EY-NC-BA}

This work is licensed under the Creative Commons Attribution-NonCommercial-ShareAlike 4.0 International License.

To view a copy of this license, visit http://creativecommons.org/licenses/by- $n c-s a / 4.0 /$ or send a letter to Creative Commons, PO Box 1866, Mountain View, CA 94042, USA.
Versiunea online a acestui articol poate fi găsită la: http://revped.ise.ro/category/2020-ro/

\section{(c) DY-NC-BA}

Această lucrare este licen iată sub Creative Commons Attribution-NonCommercial-ShareAlike 4.0 International License.

Pentru a vedea o copie a acestei licen $e$, vizita $i$ http://creativecommons.org/licenses/by-nc-sa/4.0/ sau trimite i o scrisoare către Creative Commons, PO Box 1866, Mountain View, CA 94042, SUA. 